\title{
AN OVERVIEW OF THE GASOHOL MARKET IN VIETNAM, THE NEXT DIRECTION?
}

\author{
Nghiem Thi Ngoan, Dao Minh Phuong, Pham Ba Nam \\ Vietnam Petroleum Institute \\ Email:ngoannt@vpi.pvn.vn \\ https://doi.org/10.47800/PVJ.2021.06-05
}

\section{Summary}

To ensure energy security, reduce greenhouse gas emissions and increase agricultural output, the Vietnamese government has issued several policies to promote gasohol, resulting in remarkable achievements in gasohol development in recent years. However, unexpected limitations have been seen by other countries after a period of using this fuel such as air pollution, threats to food security, deterioration of natural forest area and severely depleted freshwater resources. This paper presents an overview of the current state of Vietnam's gasohol market and a brief analysis of policy, supply - demand - price information, from which some hindrances are identified and a few more optimistic directions to develop this type of fuel in the future are proposed.

Key words: Gasohol, ethanol, feedstock.

\section{Current status of gasohol development in Vietnam}

\subsection{Gasohol related policies}

With the objectives of ensuring energy security, protecting the environment, reducing greenhouse gas emissions and stabilising agricultural product output, on 20 November 2007, the Prime Minister issued Decision No. 177/2007/QD-TTg approving the scheme for developing biofuels up to 2015 with a vision to 2025 (hereinafter referred to as "the Scheme"), aiming to increase bioethanol and vegetable oil production to 250 thousand tons by 2015 and 1.8 million tons by 2025. To implement the Scheme, on 22 November 2012, the Prime Minister signed Decision No. 53/2012/QD-TTg to promulgate a roadmap to apply the ratio of blending biofuels and traditional fuels (hereinafter referred to as "the Roadmap") with some main targets as follows:

For E5 gasoline:

- From 1 December 2014, gasoline to be produced, blended, and traded for consumption by road motor vehicles in the provinces and cities of Hanoi, Ho Chi Minh City, Hai Phong, Da Nang, Can Tho, Quang Ngai, and Ba Ria - Vung Tau would be E5.

Date of receipt: 24/6/2020. Date of review and editing: 24/6 - 22/9/2020. Date of approval: $11 / 6 / 2021$.
- From 1 December 2015, gasoline to be produced, blended, and traded for consumption by road motor vehicles in the whole nation would be E5.

For E10 gasoline:

- From 1 December 2016, gasoline to be produced, blended, and traded for consumption by road motor vehicles in the provinces and cities of Hanoi, Ho Chi Minh City, Hai Phong, Da Nang, Can Tho, Quang Ngai, and Ba Ria - Vung Tau would be E10.

- From 1 December 2017, gasoline to be produced, blended and traded for consumption by road motor vehicles in the whole nation would be E10.

According to the Government Office's Announcement No. 255/TB-VPCP dated 06/6/2017, as of 1 January 2018, only production of E5 RON 92 and RON 95 mineral gasoline would be allowed. The Government also introduced special consumption tax (SCT) incentives in Official Dispatch No. 17125/BTC-CST dated 25 November 2014. Specifically, the SCT rate for mineral gasoline is $10 \%$, for $\mathrm{E} 5$ is $8 \%$, and for $\mathrm{E} 10$ is $7 \%$. Thus, in case that $\mathrm{E} 5$ and mineral gasoline have the same taxable price, the net price of the former is $3 \%$ lower than that of the latter. These government's efforts to bring E5 gasoline closer to consumers are not strong enough to make any significant change [1]. 


\subsection{Potential feedstock for bioethanol production in Vietnam}

In Vietnam, ethanol is produced mainly from cassava the third most popular crop after rice and corn. This value chain includes stages from cassava planting, cassava slicing after harvest to blending products, distribution and use of bioethanol.

Cassava is planted mainly in lowland and plains with a slope of over $8 \%$. According to data of the General Statistics Office (GSO), the cassava planting area of the country in 2018 reached more than 566.3 thousand hectares with a total output of 9.96 million tonnes of fresh tubers. Tay Ninh is the province having the highest cassava productivity, reaching over 1.86 million tons per year, followed by Gia Lai with more than 1.18 million tons per year.

Cassava is the main feedstock for ethanol production. It is also considered the most suitable source of raw materials for bioenergy development in Vietnam based on the advantages of cultivation, the capacity to ensure supply as well as the reasonable price for long-term development. Compared to other raw materials, rice is the most important food crop ensuring food security in the country, and cannot be used as raw materials for bioalcohol production; maize productivity is inadequate to meet the needs of food and livestock in the country; sugar molasses can also produce bio-alcohol but its production cost (VND 5,000 - 10,000/kg) is higher than that of cassava while the production efficiency is lower (1 ton of sugar molasses produce 0.18 tons of ethanol while 1 ton of cassava produced 0.33 tons of ethanol) [3].

\subsection{Bioethanol production}

By 2019, Vietnam has had 7 ethanol plants with a total capacity of 612 million litres/year. Four of the plants are designed to use 1.05 million tons of cassava to produce 420 million litres of bioethanol per year for gasohol blending.

Unstable feedstock is the first difficulty that manufacturers cannot solve on their own. Although cassava is an abundant raw material in biofuel production, the lack of planning and mechanisms to help farmers develop production areas makes the supply for plants unsteady. Raw material deficiency is a crucial factor that drives many factories to operate at a high cost since raw materials account for $60 \%$ of the production cost.

The business of E5 RON 92 gasoline is conducted throughout the distribution system, thus the existing infrastructure is considered an advantage for the spreading of biofuel products. However, E5 is highly volatile fuel, resulting in the fact that transportation and storage costs as well as fuel loss are higher than those of gasoline.

Petrolimex focuses on investing in a small number of blending stations that have large capacity for distribution

Table 1. Planting area and crop productivity for bioethanol production in Vietnam [2]

\begin{tabular}{|l|c|c|c|}
\hline \multicolumn{1}{|c|}{ Content } & Corn & Sugarcane & Cassava \\
\hline Area (thousand ha) & & & 261.1 \\
\hline 2010 & $1,125.7$ & 261.0 & 498.0 \\
\hline 2018 & $1,039.0$ & 0.13 & 0.55 \\
\hline Growth 2010- 2018 (\%) & -0.96 & & \\
\hline Productivity (thousand tons) & & $16,161.7$ & $8,595.6$ \\
\hline 2010 & $4,625.7$ & $17,836.5$ & $9,960.3$ \\
\hline 2018 & $4,905.9$ & 1.43 & 2.03 \\
\hline Growth 2000- 2018 (\%) & 0.78 & & \\
\hline
\end{tabular}

Table 2. Bioethanol plants in Vietnam [4]

\begin{tabular}{|c|c|c|c|c|c|}
\hline No & Plant & Location & $\begin{array}{c}\text { Capacity (million } \\
\text { litre/year) }\end{array}$ & Operation year & Status \\
\hline 1 & Bioethanol Dung Quat & Quang Ngai & 100 & 2014 & Stop production \\
\hline 2 & Bioethanol Binh Phuoc & Binh Phuoc & 100 & 2012 & Stop production \\
\hline 3 & Ethanol Tung Lam & Dong Nai & 72 & 2011 & Operation \\
\hline 4 & Bioethanol Dai Tan & Quang Nam & 125 & 2010 & Sold to Tung Lam \\
\hline 5 & Ethanol Dac To & Kon Tum & 65 & 2011 & Operation \\
\hline 6 & Ethanol Dai Viet & Dak Nong & 50 & 2008 & Stop production \\
\hline 7 & Bioethanol Phu Tho & Phu Tho & 100 & - & Stop production \\
\hline & Total & & $\mathbf{6 1 2 / 1 9 7}$ & & Not yet operated \\
\hline
\end{tabular}


within a certain radius and that can easily be accessed by waterways or pipelines. Meanwhile, PVOIL establishes many small capacity blending stations across the country to ensure an adequate supply for the entire distribution system of 540 petrol stores of its own and more than 3,000 stores operated by general agents, agents, and franchisees.

PVOIL's strategy helps to respond quickly to the rising demand for $\mathrm{E} 5$ gasoline. It is also efficient in reducing costs, losses and time of transportation from the blending station to the distribution place, and improving the interactive support among stations if any problem occurs. This is an advantage when the bio-gasoline market becomes more popular and demand increases sharply in the short term. Petrolimex's strategy shows that the enterprise aims to be a central hub with the capability to distribute large volume, reduce labour cost, and flexibly co-ordinate when the supply-demand market of E5 gasoline fluctuates.

\subsection{Gasohol demand}

According to statistics from petroleum trading companies, E5 gasoline consumption increased rapidly in 2018 after the release of Announcement No. 255/TBVPCP. Specifically, E5 gasoline accounted for $50 \%$ of the national petrol filling stations, E5 consumption increased to 3,560 thousand $\mathrm{m}^{3}$, making up $40 \%$ of the total gasoline consumption, which previously did not exceed $9 \%$.

There are many factors affecting the demand for biogasoline such as product quality, consumer habits, and access to bio-gas stations, etc. However, price is considered the key factor, which greatly affects the demand for E5 in Vietnam.

Table 3. Domestic supply 2019 [4]

\begin{tabular}{|c|l|c|c|}
\hline No & \multicolumn{1}{|c|}{ Enterprises } & Number of blending station & Capacity (million $\mathbf{m}^{\mathbf{3}}$ ) \\
\hline 1 & Petrolimex & 7 & 1.8 \\
\hline 2 & PVOil & 12 & 1.67 \\
\hline 3 & Saigon Petro & 2 & 0.66 \\
\hline 4 & Military Petrochemical Joint Stock Company - MIPEC & 0.108 \\
\hline 5 & Nam Song Hau Petroleum Investment and Trading Co., Ltd & 0.072 \\
\hline 6 & Dong Thap Petroleum Trading Limited Company & 1 & 0.1728 \\
\hline 7 & Thanh Le Trading Import Export Company Limited & 2 & 0.576 \\
\hline 8 & Nam Phuc Investment Joint Stock Company & 2 & \\
\hline 9 & Thien Minh Duc Joint Stock Company & & 1.9 \\
\hline 10 & Trading - Investment - Investment Construction Bach KhoaViet & & \\
\hline 11 & Hai Linh Co., Ltd & & \\
\hline & Total & & \\
\hline
\end{tabular}

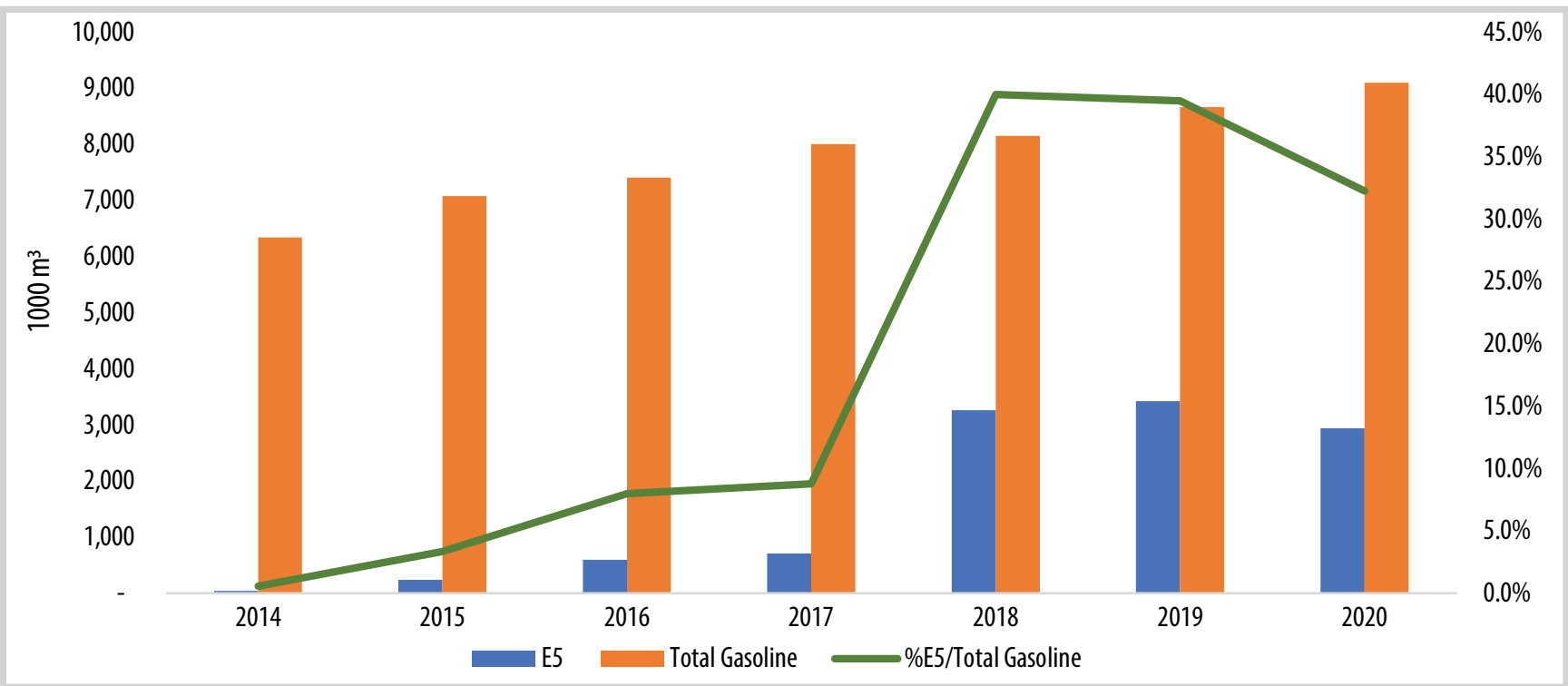

Figure 1. E5/total gasoline consumption in Vietnam during 2014 - 2020 [4]. 
Although E5 consumption increased sharply in 2018, it is trending down in the market. If in 2018, the consumed E5 was more than 3.2 million $\mathrm{m}^{3}$, equivalent to $40 \%$ of the total gasoline sold on the market, in 2020, this number decreased to $32 \%$.

This shows that the government's price supporting policy for E5 gasoline has not yielded impressive results, because the deviation between E5 and RON 95 gasoline is quite small, and not attractive enough to consumers.

In terms of demand, according to Wood Mackenzie forecast, Vietnam's gasohol development rate in the 2020
- 2025 period will be 5\% per year, equivalent to about 4 million $\mathrm{m}^{3}$; whilst the growth rate in the 2026 - 2030 period will be about 3\%, corresponding to 4.7 million $\mathrm{m}^{3}$ by 2030 .

\subsection{Gasohol prices}

Price of gasohol is described in Figures 2, 3.

The Government has incentives for E5 and mineral gasoline through the composition of excise tax, environmental protection tax, and stabilisation fund. However, the price difference between E5 and RON 95 gasoline is quite small, about VND 1,400 - 1,600/litre.

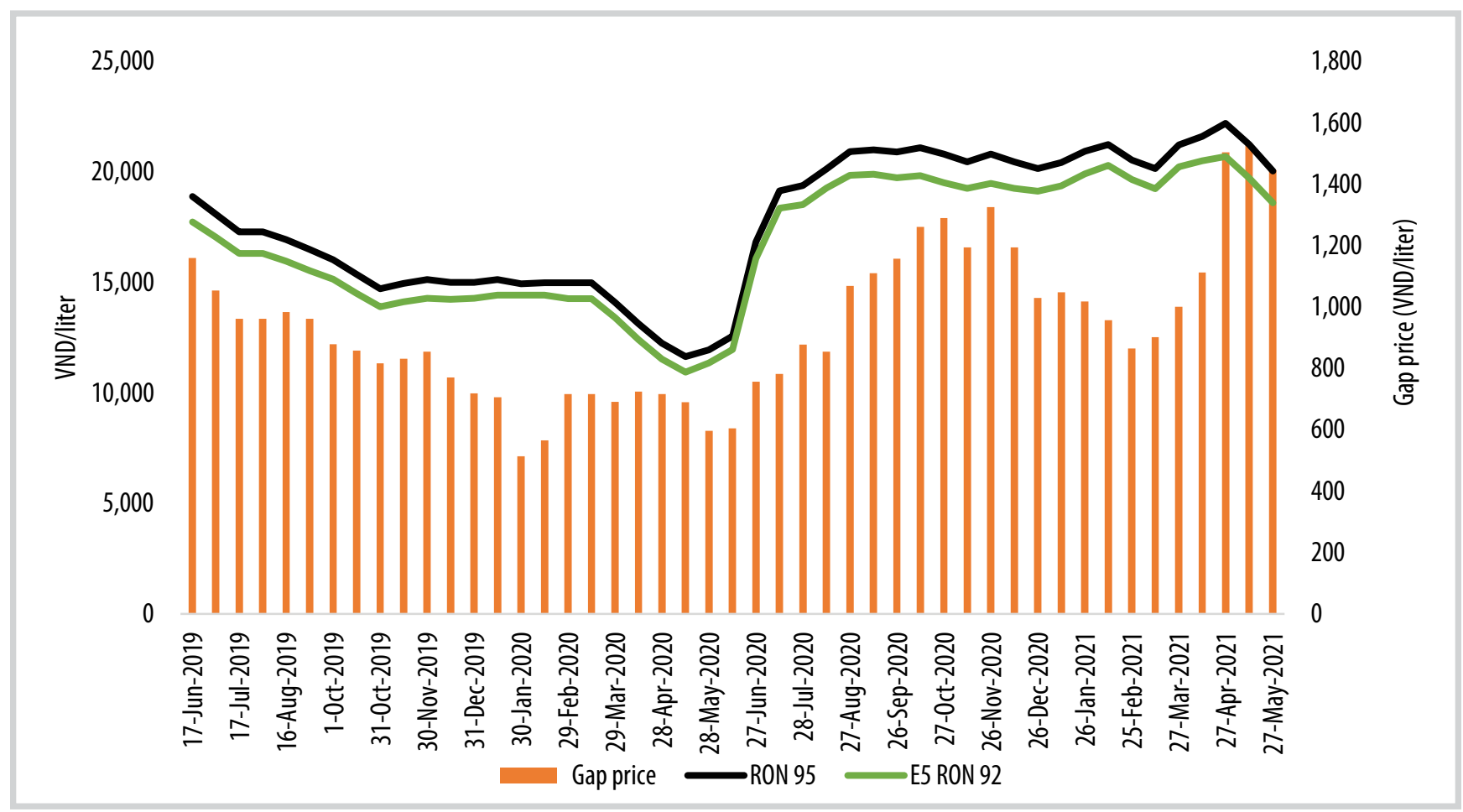

Figure 2. Retail prices of gasoline and gasohol in Vietnam [4].

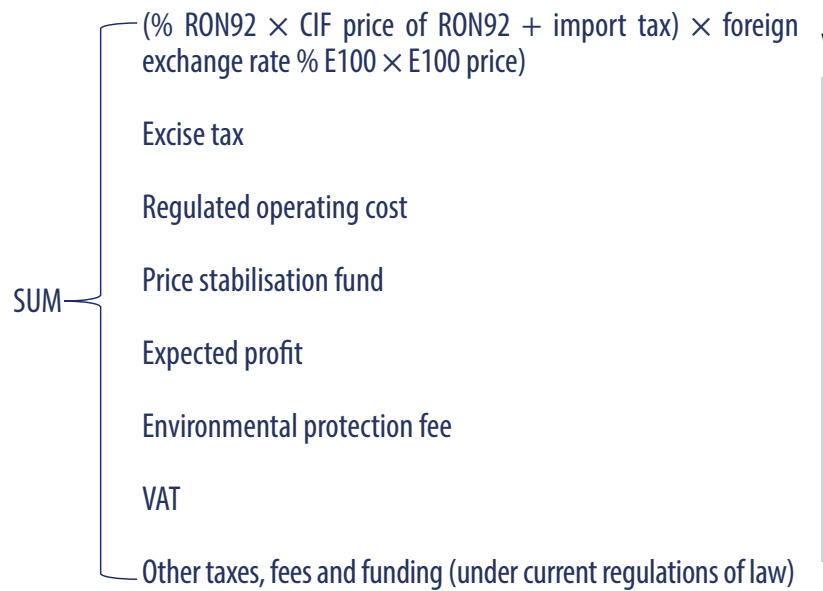

Which:

\begin{tabular}{|c|l|l|l|l|}
\hline No & \multicolumn{1}{|c|}{ Information } & Calculation unit & \multicolumn{1}{|c|}{$\begin{array}{c}\mathbf{9 5} \\
\text { gasoline }\end{array}$} & \multicolumn{1}{|c|}{ E5 } \\
\hline 1 & Excise tax & $\%$ & 10 & 8 \\
\hline 2 & Standard cost & VND/litre & 1,250 & 1,250 \\
\hline 3 & Stabilisation fund & VND/litre & \multicolumn{2}{|l|}{$\begin{array}{l}\text { Depends on each } \\
\text { petroleum business } \\
\text { management } \\
\text { documentary }\end{array}$} \\
\hline 4 & Standard profit & VND/litre & 300 & 300 \\
\hline 5 & $\begin{array}{l}\text { Environmental } \\
\text { protection fee }\end{array}$ & VND/litre & 4,000 & 3,800 \\
\hline 6 & VAT & $\%$ & 10 & 10 \\
\hline
\end{tabular}

Figure 3. Pricing structure of gasohol in Vietnam [5]. 


\section{Policies for production and use of biofuel in some countries}

Compared to other countries, Vietnam introduced gasohol to the market later. This fuel has been widely used in the US, Europe, and many developed countries since the 70s of the last century. In Southeast Asia, Thailand has been one of the biggest gasohol producers and consumers for the last 10 years.

There are various measures being used to promote gasohol development around the world, but two important policies are price subsidies and obligatory blending, with Thailand and the USA as the two representatives respectively.

Table 4. Policies of production and use of biofuels in some countries [6-8]

\begin{tabular}{|c|c|c|}
\hline Country & Biofuel mandates & Fuel excise tax reduction/exemption and other policy mechanisms \\
\hline Australia & $\begin{array}{l}\text { - No national renewable fuel target } \\
\text { - New South Wales: } 5 \% \text { biodiesel } \\
\text { and } 6 \% \text { ethanol (volume) } \\
\text { - Queensland: } 0.5 \% \text { biodiesel and } \\
4 \% \text { ethanol (volume) }\end{array}$ & - Producer grant scheme (fuel excise reduction) \\
\hline Brazil & $\begin{array}{l}\text { - } 27 \% \text { ethanol and } 10 \% \text { biodiesel } \\
\text { (volume) } \\
-100 \% \text { hydrous ethanol is also } \\
\text { marketed in all gas stations in Brazil. }\end{array}$ & $\begin{array}{l}\text { - There are tax incentives for biofuel producers, blenders and users } \\
\text { including tax incentives for ethanol-flex fuel vehicles, tax incentives for } \\
\text { ethanol fuel and federal tax exemptions and incentives for biodiesel } \\
\text { production }\end{array}$ \\
\hline Japan & $\begin{array}{l}\text { - } 500 \text { million litres of ethanol } \\
\text { mandate (volume) } \\
\text { - Introducing } 10 \text { million litres } \\
\text { (crude oil equivalent) of second } \\
\text { generation biofuels (volume) }\end{array}$ & $\begin{array}{l}\text { - No diesel oil delivery tax for B100 } \\
\text { - A special tax incentive for the consumption of ethanol } \\
\text { - Import of bio-ETBE encouraged through a zero tariff }\end{array}$ \\
\hline Sweden & $\begin{array}{l}\text { - GHG emission reduction of } 2.6 \% \\
\text { for gasoline and } 19.3 \% \text { for diesel }\end{array}$ & $\begin{array}{l}\text { - The tax exemption has varied from full to reduced tax exemption. From } \\
\text { January } 2018 \text {, all biofuels are fully exempted from tax }\end{array}$ \\
\hline $\begin{array}{l}\text { The United } \\
\text { States (US) }\end{array}$ & $\begin{array}{l}\text { - Volume targets for biofuels } \\
\text { including conventional corn-based } \\
\text { ethanol and advanced, cellulosic } \\
\text { and diesel biofuels }\end{array}$ & $\begin{array}{l}\text { - California's Low-Carbon Fuel Standard (LCFS) } \\
\text { - Biodiesel producer's credit }\end{array}$ \\
\hline India & $\begin{array}{l}\text { - No official national mandate for } \\
\text { ethanol and biodiesel use in the } \\
\text { transportation sector } \\
\text { - The } 20 \% \text { and } 5 \% \text { blending } \\
\text { targets are proposed (volume) }\end{array}$ & $\begin{array}{l}\text { - No excise tax exemption/reduction for ethanol and biodiesel } \\
\text { - Deregulated diesel prices } \\
\text { - Allow } 100 \% \text { foreign direct investment in biofuel technologies } \\
\text { - Over USD } 30 \text { million investment in biofuel R\&D and second-generation } \\
\text { ethanol technology } \\
\text { - Biofuel imports are banned but the import of feedstock for production of } \\
\text { biodiesel is permitted to the extent necessary }\end{array}$ \\
\hline Germany & $\begin{array}{l}\text { - GHG reduction of } 3.5 \% / 4 \% / 6 \% \text { in } \\
\text { the fuel mix for the entire fuel } \\
\text { sector from } 2015 / 2017 / 2020 \\
\text { onwards }\end{array}$ & $\begin{array}{l}\text { There is no tax relief for FAME biodiesel, HVO/HEFA fuels, vegetable oils and } \\
\text { ethanol: } \\
\text { - FAME biodiesel, HVO/HEFA fuels and vegetable oils have the same fuel tax } \\
\text { as diesel fuel ( } € 0.4104 / \text { litre) } \\
\text { - Ethanol has the same fuel tax as gasoline fuel ( } € 0.6545 / \mathrm{litre}) \\
\text { - The fuel tax for CNG and biomethane is } € 0.0139 / \mathrm{kWh} \text { until } 2023 \\
\text { - A carbon tax is indirectly applied via } \mathrm{CO}_{2} \text { tax for passenger cars }\end{array}$ \\
\hline Thailand & & $\begin{array}{l}\text { - An excise tax exemption and the price subsidies are provided by the State } \\
\text { Oil Fund (see Table } 5,6 \text { for details) } \\
\text { - Producers/Investors can take advantage of a 0\% import tax for equipment } \\
\text { produced outside Thailand and exemption of corporate income tax for up } \\
\text { to } 8 \text { years, with an additional } 50 \% \text { reduction for } 5 \text { years } \\
\text { - Thailand's government provides over THB } 1.5 \text { trillion (USD } 45.7 \text { million) in } \\
\text { financial support over the next } 10 \text { years to ensure success of bioeconomy } \\
\text { - The government also supports the manufacturing of vehicles that are } \\
\text { compatible with E20 and E } 85 \text { gasohol. Improvements in the fuel efficiency } \\
\text { of vehicles is promoted by setting the excise tax rate for Eco-cars (less than } \\
1,300 \text { cc engines with fuel consumption rate of no more than } 5 \text { litres per } 100 \\
\text { kilometres) at } 17 \% \text { compared to } 30 \% \text { for E10 vehicles. An additional } 3 \% \\
\text { reduction in the excise tax rate was provided for the manufacturing of Eco- } \\
\text { cars that are able to use E } 85 \text { gasohol. This helped increase annual sales of } \\
\text { E20 and E85 passenger cars, which account for approximately } 60 \% \text { of total } \\
\text { passenger cars }\end{array}$ \\
\hline
\end{tabular}


Table 5. Excise tax rates applied on gasoline and similar products in Thailand in 2019 [11]

\begin{tabular}{|c|c|}
\hline Gasoline products & Tax rate (Baht per litre) \\
\hline Unleaded gasoline & 6.50 \\
\hline Gasoline other than unleaded gasoline & 6.50 \\
\hline E10 & 5.85 \\
\hline E20 & 5.20 \\
\hline E85 & 0.975 \\
\hline
\end{tabular}

Table 6. Oil fund levied on petroleum products in Thailand in 2019 (Baht/litre) [12]

\begin{tabular}{|c|c|c|}
\hline Products & Retail price & \multicolumn{2}{c|}{ Oil fund } \\
\hline Unleaded gasoline 95 & 35.33 & 7.77 \\
\hline Gasohol 95 E10 & 27.68 & 1.81 \\
\hline Gasohol 95 E20 & 24.67 & -1.08 \\
\hline Gasohol 95 E85 & 20.04 & -6.68 \\
\hline Gasohol 91 E10 & 27.41 & 1.82 \\
\hline
\end{tabular}

In the world rankings, Thailand stood in the $6^{\text {th }}$ position in terms of ethanol production and the $7^{\text {th }}$ in terms of consumption in 2018 [9]. This country has introduced gasohol to the domestic market early, since 2002. Thailand's government imposed many policies to promote the gasohol demand and supply, of which fiscal policies are most important. By reducing excise tax and offering subsidies through the State Oil Fund, gasohol was made 20 - 40\% cheaper than the premium gasoline. These government price subsidies have led to increase of gasohol consumption up to $97 \%$ of total gasoline consumption in $2019[8,10]$. Table 5 describes more detail.

Since 2007, E10 has been introduced nationwide in Thailand. The National Oil Fund was adjusted many times lower for gasohol, especially E85. Table 6 shows the differences of this factor among the types of gasoline in 2019.

Although using gasohol can reduce $\mathrm{CO}_{2}$, bad air quality persists in Thailand's major cities. The Air Quality Index (AQI) used by cities to determine levels of air pollution measured 175 in Bangkok in January 2019, while AQI levels under 25 are considered to be acceptable for humans to breathe regularly, according to the World Health Organisation. The reason given is that ethanol increases gasoline vapour pressure (RVP), eventually leading to increased volatile organic compound (VOC) emissions and ozone. Land use change (LUC), especially change in soil carbon stock, to increase ethanol feedstock supply is an important factor in overall greenhouse gas (GHG) emissions of the first-generation biofuels, contributing about $58-60 \%$ of the net GHG emissions. In addition, the government is expected to lower the ethanol consumption target under AEDP 2015 (Thailand
Alternative Energy Development Plan 2015) to 2.6 billion litres in 2036 , down by $37 \%$ from the initial target of 4.1 billion litres, due to the uncertainty over the ability to further increase molasses and cassava supplies, the primary feedstocks for ethanol production.

The United States is the world's largest producer and consumer of gasohol, and has established a mandatory policy (The Renewable Fuel Standard - RFS) to produce and consume E10 since 2005. This programme assigns to obligated parties (fuel refiners, blenders, and importers) a renewable volume obligation (RVO). The RVO for each party is the volume of renewable fuels it is obligated to sell, based on a percentage of the company's total fuel sales. However, meeting RVO is not easy, oil refiners bear hundreds of millions of dollars each year to comply with the RFS ethanol blending requirements. Similar to Thailand, in the US, air quality has regularly been a subject of controversy. Through July 2003 in California, which had recently switched to ethanol in gasoline, the ozone exceedances in the South Coast Air Basin were twice the levels of the prior 3 years. Moreover, RFS has resulted in unintended consequences which include higher food prices, a boom-and-bust ethanol industry that is now looking to export its product. As a result, opposition to the RFS and ethanol use in the U.S. has been mounting. Twelve automotive manufacturers have even opposed any further increase above $10 \mathrm{vol} . \%$ ethanol in gasoline over concerns about corrosion of automotive components [13].

\section{Which direction for gasohol?}

It can be seen that after more than 2 decades of bio-gasoline development, the positive side of gasohol development is to reduce the dependence on mineral 
gasoline, reduce $\mathrm{CO}_{2}$ emissions, and open up opportunities for more advanced development in the future. On the other hand, the reality also indicates the limitations that the supply of raw materials is not guaranteed, consuming many fertile lands that should be used to grow food for the world's population.

The planting of crops also requires a lot of water and fertiliser, which can cause chemical residues in the soil and the lack of freshwater for people. According to a 2013 report of the United Nations Food and Agriculture Organisation (FAO), it takes 1,000-4,000 litres of water to produce 1 litre of ethanol.

Moreover, although using gasohol emit low $\mathrm{CO}_{2^{\prime}}$ contributing to reducing climate change, the process of consuming them gives off other harmful gases such as $\mathrm{CO}, \mathrm{VOC}$, and NOx which badly impact human health $[13,14]$. It was indicated by the Ministry of Environment in 2014 in Brazil, the $2^{\text {nd }}$ country in the world in terms of gasohol consumption.

Besides, many countries are turning to second- and third-generation development. Second-generation biofuels are derived from cellulose, hemicellulose, lignin or pectin, for example, waste or waste in agricultureforestry, or plant materials grown not intended for food (short-term plantations, some grasses, etc.). Thirdgeneration biofuels are derived from natural aquatic organisms (algae). These may be research directions for development because the advantages of the next generation biofuels are less usage of agriculture land, exploiting waste and saving farming area while getting higher efficiency: algae can deliver energy efficiency 60 times more than land crops and can grow in brackish water in rural areas or barren villages.

Vietnam will continue to consume gasoline in transportation in the next period, and gasohol is still more environmentally friendly than gasoline which is a type of mineral fuels. Furthermore, the energy picture in the future will be a diversification of environmentally friendly energy/fuel sources. Energy for transportation will focus on biofuel, electrical energy (for electric vehicles-EV) and hydrogen (for fuel cell electric vehicles FCEV). Specifically, EV and FCEV will be widely developed in the next $10-20$ years, and biofuels are considered as a transitional step in the gradual transition from mineral fuels to eco-friendly fuels/energy. It is a fact that many countries in the world such as Thailand, the US, and European countries still use E5, E10, and E20 gasoline, and also promote the development of electric vehicles and hydrogen vehicles. Therefore, in our point of view, for the current $\mathrm{E} 5$ production and distribution infrastructure, Vietnam should maintain a proportion of E5 gasohol from $30-40 \%$ of the total gasoline consumption as at present, stop developing E10 and set a strategy/plan to develop electric and hydrogen vehicles.

To increase the diversification of the energy resource mix for transportation, the government as well as gasohol production and distribution enterprises need to implement synchronous policies and solutions:

\section{For the government:}

- Set specific goals and a roadmap for the development and transition to environmentally friendly vehicles, including a clear biofuel development goal and a mandatory roadmap on the minimum blending ratio of biofuels for wholesalers and monitor implementation; consider supporting to develop research and application of the second- and third-generation biofuels.

- In the short-term, regional planning can be considered to meet the amount of raw materials; help farmers increase productivity; create a policy of price difference between traditional gasoline and E5 gasoline large enough to encourage consumers through environmental fees and petroleum stabilisation fund, the difference is about 15 - 20\% like Thailand's policy.

- In the long-term, impose environmental taxes $\left(\mathrm{CO}_{2}\right.$ taxes) on fossil fuels. The Environmental Law promulgated in 2020 has introduced the law on environmental tax. The implementation roadmap will be applied experimentally from now until the end of 2027 and applied officially from 2028.

For the bioethanol production enterprises:

- Ethanol production enterprises need to closely associate with cassava farmers, negotiate and sign cassava offtake contracts to ensure a stable source of input materials and harmonise the interests of the parties.

For the gasohol production and distribution enterprises:

- The wholesalers need to build a gasohol strategic plan including measures to cut costs; and improve right awareness of consumers about gasohol to promote biofuel consumption. 


\section{Conclusion}

These days, gasohol is used in over 50 countries worldwide. This is considered a solution to help protect the environment and reduce the dependence on fossil fuels. From 1 January 2018, Vietnam has applied the policy that only E5 biofuel and RON 95 would be produced and available for purchase.

However, ethanol production facilities in Vietnam sometimes struggled with a shortage of raw materials because the export price of cassava to China is higher than the domestic purchase price. Besides, the difference of retail price between E5 RON 92 gasoline and traditional gasoline is not attractive enough and people's concerns causes a trending down of the consumption E5 RON 92 gasoline from 40\% in 2018 to $32 \%$ in 2020.

In our point of view, for the current E5 production and distribution infrastructure, Vietnam should maintain a proportion of E5 gasohol from $30-40 \%$ of the total gasoline consumption as at present, stop developing E10 and set a strategy/plan to develop electric and hydrogen vehicles. The development of biofuel requires close coordination between businesses and the government while ensuring biodiversity, soil and water quality. In addition, there are some sustainable solutions which should be implemented to reduce carbon in the transportation sector including electric and hydro vehicle conversion.

\section{References}

[1] Do Xuan Dong, "The orientation in the production and use of biofuels in Vietnam", The regional workshop on "Sustainable bioenergy production and use in Southeast Asia", Ha Noi, 16 - 17 November, 2017.

[2] General Statistics Office of Vietnam. [Online]. Available: https://www.gso.gov.vn/default. aspx?tabid=717.

[3] Tạp chí Công Thương, "Bài toán nguyên liệu cho sản xuất cồn ethanol", 29/3/2017.

[4] Nghiêm Thị Ngoan và nnk, "Nghiên cứu, xây dựng báo cáo định kỳ về tình hình sản xuất và xuất nhập khẩu các sản phẩm xăng, dâu", VPI 2020.

[5] Bộ Tài chính, Thông tư liên tịch số 90/2016/TTLTBTC-BCT ngày 24/6/2016 sửa đổi, bổ sung một số điều của Thông tư liên tịch số 39/2014/TTLT-BCT-BTC ngày 29/10/2014 quy định về phương pháp tính giá cơ sở; cơ chế hình thành, quản lý, sử dụng Quỹ bình ổn giá và điều hành giá xăng dầu theo quy định tại Nghị định số 83/2014/NĐ-CP ngày 3/9/2014 của Chính phủ về kinh doanh xăng dầu. 2016.

[6] Mahmood Ebadian, James D.McMillan, Jack (John) N.Saddler, and Susan van Dy, "Implementaation agendas: 2018-2019 update compare and contrast transport biofuels policies", IEA Bioenergy, 2019.

[7] Matthew Fielding and May Thazin Aung, "Bioeconomy in Thailand: A case study", Stockholm Environment Institute, 2018.

[8] Sakchai Preechajarn, Ponnarong Prasertsri, and Maysa Chanikornpradit, "Thailand biofuels annual", United States Department of Agricultural, Foreign Agricultural Service, 15/11/2019.

[9] Narin Tunpalboon, "Thailand industry outlook 2019-21: Ethanol industry", Krungsi Research, 7/2019. [Online]. Available: https://www.krungsri.com/bank/ getmedia/0c42d6fd-18d7-41c1-9369-96dded234800/ IO_Ethanol_190710_EN_EX.aspx.

[10] Anuman Chanthawong, Shobhakar Dhakal, John K.M.Kuwornu, and Khalid Farooq, "Impact of subsidy and taxation related to biofuels policies on the economy of Thailand: A dynamic CGE modelling approach", Waste and Biomass Valorization, Vol. 11, pp. 909 - 929, 2020. DOI: 10.1007/s12649-018-0417-4.

[11] Thailand Board of Investment, "A business guide to Thailand 2019". [Online]. Available: https://www.boi. go.th/upload/content/A\%20Business\%20Guide\%20 to\%20thailand\%202019.pdf.

[12] Energy Policy and Planning Office, Ministry of Energy. [Online]. Available: http://www.eppo.go.th/index. php/en/en-energystatistics/petroleumprice-statistic.

[13] Asian Clean Fuels Association, "Biofuel experiences in Southeast Asia", 2019.

[14] Larry G. Anderson, "Ethanol fuel use in Brazil: Air quality impacts", Energy \& Environmental Science, Vol. 2, pp. 1015 - 1037, 2009. DOI: 10.1039/B906057J. 